\title{
Prevalence of the most common Reproductive Tract Infections among women attending family Planning clinics in Montazah- Alexandria
}

\author{
Amal Philip**, Ahmed E. Shouman*, Sahar A. Dewedar* and Dina N. K.Boulos* \\ * Department of community Environmental and Occupational Medicine, Faculty of \\ Medicine, Ain Shams University \\ **Population and Family Planning Sector, Ministry of Health and Population
}

\begin{abstract}
Background: The global burden of reproductive tract infections (RTIs) is enormous and of a major public health concern, particularly in developing countries where RTIs are endemic. RTIs constitute the second major cause of disease burden (after maternity related causes) in young adult women in developing countries. Aim of work: To measure the prevalence of Candida albicans, Trichomonas vaginalis and Bacterial vaginosis among married women and to identify some factors associated with them. Subject and methods: a cross sectional descriptive study was conducted in four health centers in El -Montazah health district-Alexandria. All women seeking family planning services at these clinics were included in the study till fulfilling the calculated sample size. An interview questionnaire, clinical examination and laboratory diagnosis were implemented on studied participants. Result: The study revealed that 484/615 (78.7\%) studied women had at least one type of reproductive tract infections based on laboratory test. Candida albicans constituted $(48.1 \%)$, Bacterial Vaginosis constituted (28.9\%), mixed Candidiasis and Bacterial Vaginosis constituted (15.4\%) Trichomonas vaginalis constituted $(4.1 \%)$ mixed Trichomonas and Candidiasis and / or Bacterial Vaginosis constituted (3.3\%). Education and employment were found to be significantly associated with reproductive tract infections however age and parity were not significantly associated with RTIs. Conclusion: RTIs are prevalent among women attending the family planning clinics. Both education and employment influence the presence of RTIs.
\end{abstract}

Recommendation: As family planning is often a woman's primary, and sometimes sole contact with the health care system; it is recommended to integrate RTI saeening $\&$ management with family planning services

\section{Introduction}

Reproductive tract infections (RTIs) are infections of the genital tract. Some are sexually transmitted. Overgrowth of endogenous microorganisms normally found in the vagina may cause RTIs Medical interventions may provoke iatrogenic infection. (1)(2)(3)

"Reproductive tract infections" is a global public health problem, mostly ignored by many women. Since a large proportion of women, suffer morbidity silently, and are reluctant to seek care ${ }^{(4)}$

The global burden of reproductive tract infections (RTI's) is enormous and of a major public health concern, particularly in developing countries where RTIs are endemic. RTIs, excluding Human Immunodeficiency Virus (HIV) constitute the second major cause of disease burden (after maternity related causes) in young 
adult women in developing countries (1).

Three common infections are associated with vaginal discharge bacterial vaginosis, Trichomoniasis and candidiasis, of which Trichomoniasis is a sexually transmitted infection. ${ }^{(\mathbf{5})}$

In Egypt 2001, a study implemented in a house-to-house survey using cluster sampling of 1344 married women from urban and rural areas of Upper Egypt the overall prevalence of RTIs was found to be $52.8 \%$, with the most prevalent forms being Candida albicans (28.0\%), Trichomonas vaginalis $\quad(8.7 \%)$, Aspergillus species (7.4\%), Bacterial Vaginosis and streptococci $(4.6 \%)$ and Chlamydia trachomatis $(4.2 \%)^{(6)}$

Many women in Middle East and North Africa countries suffer from RTIs caused by lack of clean water for bathing and unclean practices during delivery or abortion. RTIs can cause persistent pain and discomfort, diminish women's productivity and quality of life. Many women do not realize they have a treatable RTI, because they have been taught to accept the symptoms as part of being a woman. ${ }^{(7)}$

RTI preventive programs should be integrated into other reproductive health care programs such as family planning, maternal and child health services ${ }^{\text {(1) }}$

The number of studies conducted in RTIs arena in Egypt is limited; studies are needed to identify the magnitude of the problem to determine the necessary intervention.

\section{The aim of the work:}

1. To measure the prevalence of Candida albicans, Trichomonas vaginalis and Bacterial vaginosis among married women attending family planning clinics in Elmontazah district-Alexandria.

2. To identify some factors associated with Candida albicans, Trichomonas vaginalis and Bacterial vaginosis among married women attending family planning clinics in El-montazah district-Alexandria.

\section{Methodology}

Study design: This is a cross sectional descriptive study.

Study population and site: Four health centers out of 18 health centers including family planning clinics were randomly selected from AlMotazah health district. All women seeking family planning services at these clinics were included in the study till fulfilling the calculated sample size.

Inclusion criteria: Age from 15 - 49 years, married women, have no bleeding and not pregnant.

Sample size: Using Epi info statistical package. The main aim of the study was to determine the prevalence of RTIs among married women attending four family planning clinics. The prevalence rate of RTIs among married women was detected from a study of "Reproductive tract infections among married women in Upper Egypt to be $52.8 \%{ }^{(6)}$

At $95 \% \mathrm{CI}$ and power $80 \%$,expected frequency of $52.8 \%$ and worst acceptable frequency of $48 \%$, a sample size of at least 407 was required and after adjusting for $10 \%$ drop out a sample size of 450 was suggested however 615 specimen were collected.

Study tools: An interview questionnaire was used and included: 1- Socio demographic data, Present 
history of Contraception method, Symptoms of reproductive tract infections. 2- Clinical examination sheet: The trained service providers examined the study participants clinically and recorded the symptoms and signs. 3-Laboratory diagnosis using Wet mount microscopic examination to detect motile Trichomonas and Candida albicans and Gram stain microscopy of vaginal smear to detect Bacterial vaginosis ${ }^{(8)}$.

Operational definition of the case of RTIs that we used: a client attending family planning clinic is considered to be a case of RTI if confirmed by laboratory (by microscopic diagnosis) to be one or more infection by Candida albicans, Trichomonas vaginalis and Bacterial vaginosis.

\section{Ethical consideration}

- Approval from the Ain shams University Ethical Review committee and from the family planning sector at the Ministry of health and population was obtained before the beginning of the study.

- Informed Consent was obtained from all study participants after explaining the aim and the nature of the study and assuring participants that confidentiality is maintained throughout the work.

\section{Data management}

All collected forms were revised for completeness, and logical consistency. Pre-coded data was entered on the statistical package of Social Science, version 19 (SPSS19). Frequency tables and graphs were used to describe the sample population; Chi-square tests were used to compare qualitative variables and $\mathrm{t}$ test for continuous variables.

\section{Results}

A total of 615 women from four family planning clinics participated in the study, $29.4 \%$ of participants from Al-Amrawy health center; 27.2\% from Al-Mandara health center; 26.5\% from Al-Montazah Al-Refia health center and $16.9 \%$ from family planning clinic inside General Abokeer hospital. The age range was 18-49 years and the majority of participants $(71.5 \%)$ were in the age group (20-34years) . Of all participants $38.4 \%$ were illiterate; $7.5 \%$ had primary or preparatory school; $(40.1 \%)$ had technical diploma and $14.1 \%$ had high education. The majority of participants $(82.1 \%)$ were not working. Five hundred and eighty eight women accounting for 95.6\% were using family planning methods. About two third of participants had 2 or 3 children $(61.3 \%)$. Also $21.5 \%$ of participants visited family planning clinic seeking medical advice for RTIs. (Table 1)

The study showed $78.7 \%$ of studied women had reproductive tract infections based on laboratory test. (Figure1)

The most prevalent RTIs in the study participants was candida albicans accounting for $48.1 \%$ followed by Bacterial Vaginosis constituting $28.9 \%$, mixed Candidiasis and Bacterial Vaginosis were prevalent in $15.4 \%$ Trichomonas vaginalis $4.1 \%$ and mixed Trichomonas and Candidiasis and / or BacterialVaginosis : 3.3\%. (figure2)

It was found that the prevalence of RTIs was 91.1\% among illiterate women compared to $50 \%$ among highly educated and the difference was statistically significant $\mathrm{p}<0.001$. Concerning employment status the prevalence of RTI was $84.4 \%$ in women who are not working while it 
was $52.7 \%$ in working women and the difference was statistically significant $\mathrm{p}<0.001$. As regard age and parity there is no statistical significant difference. (Table 2)

It was found that $73.5 \%$ of studied participants reported that they have symptoms suggesting presence of RTIs. Vaginal discharge was the main presenting symptom accounting for $43.3 \%$ followed by vulval itching $25.4 \%$. By clinical examination white cheesy discharge was the main sign accounting for $41.5 \%$ followed by nonspecific discharge $(34.2 \%)$ then yellow frothy discharge (16.5\%). (Table 3)

The prevalence of RTI was $80.4 \%$ among women who were using progestin only contraceptive methods; 79.2\% among both intrauterine device (IUD) and combined methods' users while the lowest prevalence of RTIs is among women whose husbands were using condom $(56.3 \%)$ \& there is no statistically significant difference. (Table 4)

Prevalence of RTIs was $84 \%$ among women who were complaining from vaginal discharge, $85.2 \%$ among women complaining from abdominal or back pain and $63.8 \%$ among women not complaining from any symptoms of RTIs on direct question. The prevalence of RTIs was $91.2 \%$ among women with yellow frothy discharge and $88.2 \%$ among women with white cheesy discharge, while the lowest prevalence of RTIs $50.8 \%$ is among women free from signs of RTIs. (Table 5)

The prevalence of RTIs was $85.6 \%$ among women who attended the clinics complaining of RTIs and $77.8 \%$ among women who attended the clinic for routine visit. (Table 6)
The prevalence of symptoms of RTIs was $94.9 \%$ among women with past history of RTIs during the year preceding the study. Regarding site of seeking medical care for the RTIs during the last year preceding the study, the prevalence of RTIs was $94.4 \%$ among women who sought treatment from primary health care units; 96.2\% among women who used home remedies and 98\% among women who did not seek any medical advice to treat the previous attack of RTIs. (Table 7)

\section{Discussion}

The study showed that $21.5 \%$ of participants visited family planning clinic seeking medical advice for RTIs, while based on laboratory test $484 / 615(78.7 \%)$ of studied women had reproductive tract infections versus $73.5 \%$ based on the symptoms only with direct question to women and $89.8 \%$ based on the clinical examination only. These findings were in accordance with the results of a cross section study done in India using a simple random sampling technique on 656 women of 15-45 years as there is no big differences between diagnosis based on laboratory test in comparison with diagnosis based on symptoms or clinical examination, where the prevalence of RTIs among women was $40.4 \%$ based on their symptoms, $37.4 \%$ based on clinical finding and $34.3 \%$ based on laboratory test. ${ }^{(4)}$

In the present study Candida albicans constituted $48.1 \%$, Bacterial Vaginosis 28.9\%, mixed Candidiasis and Bacterial Vaginosis 15.4\% Trichomonas vaginalis $4.1 \%$ Trichomonas and Candidiasis and / Bacterial Vaginosis 3.3\% .

Causes of RTIs are similar to a study implemented in India in which the laboratory test revealed that 
Candidiasis (16.1\%) followed by Bacterial vaginosis (12.5\%) and Trichomoniasis (4.27\%) ${ }^{(4)}$ And a study implemented in Vietnam in which the prevalence of Candidiasis was $26 \%$, Bacterial vaginosis was $11 \%$ and Trichomonas was $1 \%$.

(9)

In this study multiple infections were common as $18.8 \%$ of participants had two RTIs, this is similar to study implemented in China in which $20.4 \%$ of study group had two RTIs. ${ }^{(10)}$

The present study revealed that the presence of RTIs was not influenced by age (mean age among free women and those having RTIs was $30.76 \pm 6.48$ and $30.19 \pm 6.18$ respectively). Similarly the parity didn't influence RTIs occurrence (mean number of children among free women and those having RTIs was $2.30 \pm 1.13$ and $2.31 \pm 1.09$ respectively) this is in accordance with a house to house survey done in Egypt using cluster sampling on 1344 married women from Upper Egypt to study the magnitude and determinants of reproductive tract infections. This study showed that the pattern of RTIs was not influenced by age and parity. (6)

In the present study the prevalence of RTIs was $91.1 \%$ among illiterate women and showed a decreased trend with an increase in level of education as it was $50 \%$ among highly educated $(p<0.001)$ this finding is in accordance with a study done in India in which it was reported that the maximum prevalence of RTIs was found among illiterate women (76.19\%) and gradually decreased as the education of women increased as it was $44.8 \%$ among highly graduated women ${ }^{(11}$ ) and a study done in Iran to determine the prevalence and risk factors of reproductive tract infections among a defined population of Iranian women reported that low educational levels (illiterate and under diploma level) were the risk factors for these infections. ${ }^{(\mathbf{1 2})}$

Concerning employment status in the current study, the prevalence of RTI was $84.4 \%$ in women who are not working while it was $52.7 \%$ in women who are working $(\mathrm{p}<0.001)$ and this is in accordance with a study done in India that reported $38 \%$ of women who were home makers had RTIs against $26 \%$ of employed women. ${ }^{(4)}$

The current study revealed that the presence of RTIs was not influenced by any contraceptive method. This finding agrees with the study done in India that showed that the prevalence of RTI/STI was similar in users and non user of any contraceptives. The differences were statistically insignificant. ${ }^{(13)}$

In the present study the most common reported symptom was discharge accounting for $43.3 \%$; vaginal itching $25.4 \%$ abdominal /back pain (18\%) and dyspareunia $(11.2 \%)$. This is similar to the study done in Lagos, Nigeria in which vaginal discharge was the commonest symptom accounting for $21.8 \%$ vulval itching (17.7\%), lower abdominal pain $15.0 \%$ and pain dysparounia $2.7 \%{ }^{(\mathbf{1 4}}$ ) and similar to the study done in Beirut, Lebanon in which vaginal discharge was the most commonly reported symptom, with $33 \%$ of currently married women complaining of ${ }^{(\mathbf{1 5})}$

Also the current study revealed that there is a statistically significant difference between the current symptoms and the presence of RTIs as the prevalence of RTIs was $84 \%$ among women who were complaining of vaginal discharge; $85.2 \%$ among women complaining of 
abdominal / back pain; $83.5 \%$ among women complaining of vaginal itching and $84.3 \%$ among women complaining of dyspareunia. This finding is disagreeing with a study done in Egypt that reported that symptoms mentioned by the women were of low discriminating value in detecting RTIs. ${ }^{(6)}$

In the present study the most common sign was white cheesy discharge accounting for $41.5 \%$, nonspecific discharge $34.2 \%$ and bad vaginal smell $7.8 \%$. Also the study revealed a statistically significant difference between the signs discovered by clinical examination and the presence of RTIs as the prevalence of RTIs was $91.2 \%$ among women with yellow frothy discharge and $88.2 \%$ among women with white cheesy discharge and $69.3 \%$ among women with nonspecific vaginal discharge.

This finding is in accordance with the study done in Egypt in which it was reported that clinical signs detected by the gynecological examination were significantly associated with presence of RTIs. ${ }^{(6)}$

In the present study $70.2 \%$ of studied women suffered from at least one attack of RTIs during their last year among them 89\% sought medical care. The primary health care units were the main facilities where treatment was sought accounting for $(42.1 \%)$ while $36.6 \%$ of studied women used home remedies and $10.9 \%$ ignored the symptoms.

These findings are in accordance with the study done in Lagos, Nigeria in which $37.4 \%$ of respondents had experienced at least one symptom in the previous six months. The majority of those who reported symptoms $(87.9 \%)$ sought medical treatment. Only $9.9 \%$ treated themselves while $2.2 \%$ ignored symptoms. Government health centers were the most visited health facilities for treatment $(32.5 \%)$ followed by pharmacy $(22.5 \%){ }^{(13) .}$ The difference in reported prevalence of RTIs among Nigerian women and current study being lower in Nigeria's study can be attributed to the fact that the current study inquired about prevalence of RTIs in the year preceding the study while the other study inquired about only six months preceding the study.

\section{Conclusion \\ Recommendations}

and

Highly RTIs are prevalent and very high among women attending the family planning clinics as it was $78.7 \%$ based on laboratory test. The study highlights the need for raise the awareness of community regarding protection of RTIs. Both education and employment influence the presence of RTIs. The primary health care units were the main facilities where treatment was sought (42.1\%). The findings of this study could be used to improve the quality of RTIs patients care. Because family planning is often a woman's primary and sometimes sole contact with the health care system; it is recommended to integrate RTIs management with family planning services.

\section{References}

1) World Health Organization WHO (2005): Sexually Transmitted and Other Reproductive Tract Infections. A guide to essential practice. Available at: http://whqlibdoc.who.int/publicatio ns/2005/9241592656.pdf

2) Population Council (2013): Reproductive Tract Infections. An Introductory overview. Available at: http://www.popcouncil.org/uploads/p dfs/RTIFacsheetsRev.pdf Accessed at September 2013. 
3) Center for Disease Control and Prevention CDC (2003): Reproductive Tract Infection, reproductive health epidemiology series, MODULE 3 June 2003. Atlanta, Georgia U.S.A.

4) Sangeetha $S$ Balamurugan and Bendigeri N D (2012): Community-Based Study of Reproductive Tract Infections among Women of the Reproductive Age Group in the Urban Health Training Centre Area in Hubli, Karnataka. Indian .J Community Med. 2012 Jan-Mar; 37(1): 34-38.

\section{5) European (IUSTI/WHO)}

Guideline on the Management of Vaginal Discharge (2011):

available at:

http://www.iusti.org/regions/europe /pdf/2011/Euro_Guidelines_Vagina 1 Discharge 2011.Intl Jrev.pdf

Accessed in April 2014

6) Sallam SA, Mahfouz AA, Dabbous NI, el-Barrawy M, elSaid MM (2001):

Reproductive tract infections among married women in Upper Egypt.East Mediterranean Health J. 2001 Jan-Mar;7(1-2):139-46.

7) Population Reference Bureau PRB (2003): Women's reproductive health in the Middle East and North Africa, by Farzaneh Roudi-Fahimi. Available at: http://www.prb.org/pdf/womensrep rohealth eng.pdf. Accessed at March 2014

8) National guideline for management of sexually transmitted diseases Egypt (2006): Egyptian ministry of health and population. Available at: http://www.ilo.org/wcmsp5/groups/ public/---ed_protect/---protrav/--ilo aids/documents/legaldocument/ wcms 127521.pdf
9) Lan PT, Lundborg CS, Phuc HD, Sihavong A, Unemo $M$, ChucNTandKhang TH, Mogren I (2008): Reproductive tract infections including sexually transmitted infections: a population-based study of women of reproductive age in a rural district of Vietnam. Sex Transm Infect. 2008 Apr;84(2):126-32. Epub 2007 Nov 14.

10) Zhang $X J$, Shen $Q$, Wang GY, Yu YL, Sun YH, Yu GB, Zhao D, Ye DQ.(2009): Risk factors for reproductive tract infections among married women in rural areas of Anhui Province, China Eur J ObstetGynecolReprod Biol. 2009 Dec;147(2):187-91.

11) Komal P. Thekdi, K. G. Patel, Nita K. Patel, Pukur I. Thekdi (2014):

A cross sectional study on the prevalence of reproductive tract infections amongst married women in the rural area of Surendranagar district. Int J Res Med Sci. 2014; 2(1): 215-221.

12) Maharlouei N, Barooti E, Sharif F, Hosseini $H$ and Lankarani KB (2009):

Prevalence and risk factors of reproductive tract infections among a defined population of Iranian women.Sex Health. 2013 Aug;10(4):311-5

13) Preethi S. Philip, Anoop I. Benjamin, and Paramita Sengupta.(2013): Prevalence of symptoms suggestive of reproductive tract infections/sexually transmitted infections in women in an urban area of Ludhiana,Indian $\mathbf{J}$ Sex Transm Dis. 2013 Jul-Dec; 34(2): 83-88. 
14) Kabiru A Rabiu,Adeniyi A Adewunmi, Fatimat M Akinlusi and Oluwarotimi I Akinola (2010) : Female reproductive tract infections: understandings and care seeking behavior among women of reproductive age in Lagos, Nigeria. BMC Women's Health. 2010 Mar $23 ; 10: 8$
15) Khawaja M, Kaddour A, Zurayk H, Choueiry N and ElKak F(2008):_Symptoms of reproductive tract infections and mental distress among women in low-income urban neighborhoods of Beirut, Lebanon.J Womens Health (Larchmt). 2009 Oct;18(10):1701-8. 
Table (1) Characteristics of studied women

\begin{tabular}{|c|c|c|}
\hline Variable & $\begin{array}{l}\text { Frequency } \\
(n=615)\end{array}$ & $\%$ \\
\hline \multicolumn{3}{|l|}{ Health center } \\
\hline Al-Amrawy & 181 & 29.4 \\
\hline Al-Mandara & 167 & 27.2 \\
\hline Al-Montazah al-Refia & 163 & 26.5 \\
\hline Abo-Keer hospital & 104 & 16.9 \\
\hline \multicolumn{3}{|l|}{ Age in years } \\
\hline $18-24$ & 11 & 1.8 \\
\hline $20-24$ & 126 & 20.5 \\
\hline $25-29$ & 176 & 28.6 \\
\hline $30-34$ & 138 & 22.4 \\
\hline 35- 39 & 93 & 15.1 \\
\hline $40-44$ & 45 & 7.3 \\
\hline $45-49$ & 26 & 4.2 \\
\hline \multicolumn{3}{|l|}{ Education } \\
\hline Illiterate & 236 & 38.4 \\
\hline Primary and preparatory school & 46 & 7.5 \\
\hline $\begin{array}{l}\text { Intermediate education (technical } \\
\text { diploma) }\end{array}$ & 247 & 40.1 \\
\hline High institute and faculties & 86 & 14.0 \\
\hline \multicolumn{3}{|l|}{ Employment } \\
\hline Working & 110 & 17.9 \\
\hline Not working & 505 & 82.1 \\
\hline \multicolumn{3}{|l|}{ Number of offspring } \\
\hline No children & 10 & 1.6 \\
\hline One child & 151 & 24.6 \\
\hline Two children & 196 & 31.9 \\
\hline Three children & 181 & 29.4 \\
\hline Four children and more & 77 & 12.5 \\
\hline \multicolumn{3}{|l|}{ Family planning practice } \\
\hline Users & 588 & 95.6 \\
\hline Non users & 27 & 4.4 \\
\hline \multicolumn{3}{|l|}{ Cause of visit the clinic } \\
\hline RTIs examination & 132 & 21.5 \\
\hline Routine visit & 483 & 78.5 \\
\hline
\end{tabular}


Table (2) RTIs distribution according to socio demographic characteristics

\begin{tabular}{|c|c|c|c|c|}
\hline \multirow[t]{2}{*}{ Variable } & \multicolumn{2}{|c|}{ RTIs status } & \multirow[b]{2}{*}{ Total } & \multirow[t]{2}{*}{$\begin{array}{l}\text { Test of } \\
\text { significance }\end{array}$} \\
\hline & $\begin{array}{c}\text { Free of RTIs } \\
\mathbf{N}=131 \\
\mathrm{~N}(\%)\end{array}$ & $\begin{array}{c}\text { +ve RTIs } \\
\text { N=484 } \\
\text { N(\%) }\end{array}$ & & \\
\hline $\begin{array}{l}\text { Education } \\
\text { illiterate } \\
\text { Primary \& prep } \\
\text { Intermediate } \\
\text { High education }\end{array}$ & $\begin{array}{c}21(8.9 \%) \\
10(21.7 \%) \\
57(23.1 \%) \\
43(50 \%)\end{array}$ & $\begin{array}{c}215(91.1 \%) \\
36(78.3 \%) \\
190(76.9 \%) \\
43(50 \%)\end{array}$ & $\begin{array}{c}236 \\
46 \\
247 \\
86\end{array}$ & $\begin{array}{c}x 2=64.380 \\
p=0.000\end{array}$ \\
\hline $\begin{array}{l}\text { Employment } \\
\text { working } \\
\text { Not working }\end{array}$ & $\begin{array}{l}52(47.3 \%) \\
79(15.6 \%)\end{array}$ & $\begin{array}{c}58(52.7 \%) \\
426(84.4 \%)\end{array}$ & $\begin{array}{l}110 \\
505\end{array}$ & $\begin{array}{c}x 2=53.904 \\
\mathrm{P}=0.000\end{array}$ \\
\hline $\begin{array}{l}\text { Age } \\
\bar{x}+S D\end{array}$ & $30.76+6.48$ & $30.19+6.18$ & \multicolumn{2}{|c|}{$\begin{array}{c}\mathrm{t} \text { test }=0.863 \\
\mathrm{p} \text { value }=0.389\end{array}$} \\
\hline $\begin{array}{l}\text { Parity } \\
\overline{\mathrm{x}} \pm \mathrm{SD}\end{array}$ & $2.30+1.13$ & $2.31+1.09$ & \multicolumn{2}{|c|}{$\begin{array}{c}\mathrm{t} \text { test }=0.093 \\
\mathrm{p} \text { value }=0.926\end{array}$} \\
\hline
\end{tabular}


Table (3) Presenting signs and symptoms among studied women

\begin{tabular}{|l|c|c|}
\hline \multicolumn{1}{|c|}{ Status } & Frequency & $\%$ \\
\hline Symptoms & & \\
& 163 & 26.5 \\
No symptoms & 452 & 73.5 \\
Symptoms & 615 & 100.0 \\
Total & & \\
\hline Reported symptom & 43.3 \\
Discharge & 196 & 25.4 \\
Vulval Itching & 81 & 18.0 \\
Abdominal or back pain & 51 & 11.2 \\
Dyspareunia & 9 & 2 \\
Bad smell discharge & 452 & 100.0 \\
Total & & \\
\hline Clinical examination & 63 & 10.2 \\
Clinically free & 552 & 100 \\
\hline Had sign of RTIs & 615 & \\
Total & & 41.5 \\
\hline Signs by clinical examination & 229 & 34.2 \\
White cheesy discharge & 189 & 16.5 \\
Nonspecific discharge & 91 & 100 \\
\hline Yellow frothy discharge & 43 & \\
Bad smell discharge & 552 & \\
\hline Total & & \\
\hline
\end{tabular}

Table (4) Distribution of RTIs according to contraceptive methods used

\begin{tabular}{|l|c|c|c||c|}
\hline \multirow{2}{*}{\begin{tabular}{c}
\multirow{2}{*}{$\begin{array}{c}\text { Type of } \\
\text { contraceptive } \\
\text { Method }\end{array}$} \\
\cline { 2 - 3 }
\end{tabular}} & $\begin{array}{c}\text { Free } \\
\mathrm{N}=131 \\
\mathrm{~N}(\%)\end{array}$ & $\begin{array}{c}\text { Affecyed } \\
\mathbf{N}=484 \\
\mathrm{~N}(\%)\end{array}$ & \multirow{2}{*}{ Total } & \multirow{2}{*}{$\begin{array}{c}\text { Test of } \\
\text { significance }\end{array}$} \\
\hline IUD & $48(20.8)$ & $183(79.2)$ & 231 & \multirow{2}{*}{$\mathrm{X}^{2}=6.402$} \\
\hline Combined methods & $22(20.8)$ & $84(79.2)$ & 106 & $\mathrm{P}=0.171$ \\
\hline Progestin only methods & $46(19.6)$ & $189(80.4)$ & 235 & \\
\hline Condom & $7(43.8)$ & $9(56.3)$ & 16 & \\
\hline Non users & $8(29.6)$ & $19(70.4)$ & 27 & \\
\hline
\end{tabular}


Table (5) RTIs distribution according to symptoms and signs of RTIs among studied women

\begin{tabular}{|c|c|c|c|c|}
\hline \multirow[t]{2}{*}{ Variable } & \multicolumn{2}{|c|}{ RTIs Status } & \multirow[t]{2}{*}{ Total } & \multirow{2}{*}{$\begin{array}{c}\text { Test of } \\
\text { significance }\end{array}$} \\
\hline & $\begin{array}{c}\text { Free } \\
\mathbf{N}=131 \\
\mathbf{N}(\%) \\
\end{array}$ & $\begin{array}{c}\text { Afected } \\
\mathrm{N}=484 \\
\mathrm{~N}(\%) \\
\end{array}$ & & \\
\hline $\begin{array}{l}\text { Symptom on direct question } \\
\text { Vaginal discharge } \\
\text { Abdominal or back pain } \\
\text { Vulval itching } \\
\text { Dyspareunia } \\
\text { No complaint }\end{array}$ & $\begin{array}{c}33(16.0) \\
12(14.8) \\
19(16.5) \\
8(15.7) \\
59(36.2)\end{array}$ & $\begin{array}{c}172(84) \\
69(85.2) \\
96(83.5) \\
43(84.3) \\
104(63.8)\end{array}$ & $\begin{array}{c}205 \\
81 \\
115 \\
51 \\
163\end{array}$ & $\begin{array}{c}\mathrm{X}^{2}=9.583 \\
\mathrm{P}=0.000^{*}\end{array}$ \\
\hline $\begin{array}{l}\text { Signs on examination } \\
\text { Nonspecific vaginal discharge } \\
\text { White cheesy discharge } \\
\text { Yellow frothy discharge } \\
\text { Bad odor } \\
\text { Free }\end{array}$ & $\begin{array}{c}58(30.7) \\
27(11.8) \\
8(8.8) \\
7(16.3) \\
31(49.2)\end{array}$ & $\begin{array}{c}131(69.3) \\
202(88.2) \\
83(91.2) \\
36(83.7) \\
32(50.8)\end{array}$ & $\begin{array}{c}189 \\
229 \\
91 \\
43 \\
63\end{array}$ & $\begin{array}{l}X^{2}=60.698 \\
P=0.000^{*}\end{array}$ \\
\hline
\end{tabular}

Table (6) RTIs distribution according to the reason of visit the facility

\begin{tabular}{|c|c|c|c||c|}
\hline \multirow{2}{*}{$\begin{array}{c}\text { Cause of visit the } \\
\text { facility }\end{array}$} & \multicolumn{2}{|c||}{ RTIs Status } & $\begin{array}{c}\text { Test of } \\
\text { significance }\end{array}$ \\
\cline { 2 - 3 } & \multicolumn{2}{|c|}{ Total } & \\
\cline { 2 - 3 } & $\mathrm{N}=131$ & $\mathrm{~N}(\%)$ & $\mathrm{N}=484$ \\
$\mathrm{~N}(\%)$ & & \\
\hline RTI examination & $19(14.4)$ & $113(85.6)$ & 132 & $\begin{array}{r}\mathrm{X}^{2}=15.769 \\
\mathrm{p}=0.000^{*}\end{array}$ \\
\hline Routine clinic visit & $105(22.2)$ & $367(77.8)$ & 472 \\
\hline Infertility or counseling & $7(63.6)$ & $4(36.4)$ & 11 & \\
\hline
\end{tabular}


Table (7) RTIs distribution according to Past history of RTIs in the year preceding the study and Site of seeking medical care

\begin{tabular}{|c|c|c|c|c|}
\hline \multirow[b]{2}{*}{ variable } & \multicolumn{2}{|c|}{ RTIs Status } & \multirow[b]{2}{*}{ Total } & \multirow{2}{*}{$\begin{array}{c}\text { Test of } \\
\text { significance }\end{array}$} \\
\hline & $\begin{array}{l}\text { Free } \\
\mathrm{N}(\%)\end{array}$ & $\begin{array}{l}\text { Afected } \\
\text { RTIs } \\
\text { N(\%) }\end{array}$ & & \\
\hline $\begin{array}{l}\text { Past history of RTIs } \\
\text { Yes } \\
\text { No }\end{array}$ & $\begin{array}{c}22(5.1) \\
109(59.6)\end{array}$ & $\begin{array}{c}410(94.9) \\
74(40.4)\end{array}$ & $\begin{array}{l}432 \\
183\end{array}$ & $\begin{aligned} X^{2} & =227.516 \\
p & =0.000^{*}\end{aligned}$ \\
\hline Total & 131(21.7) & $484(78.7)$ & 615 & \\
\hline $\begin{array}{l}\text { Site of seeking medical care } \\
\text { Private clinic } \\
\text { Primary Health unit/general hospital } \\
\text { Pharmacy } \\
\text { Home remedies } \\
\text { Ignored }\end{array}$ & $\begin{array}{c}4(13.8) \\
10(5.6) \\
1(6.3) \\
6(3.8) \\
1(2) \\
\end{array}$ & $\begin{array}{c}25(86.2) \\
169(94.4) \\
15(93.8) \\
153(96.2) \\
48(98) \\
\end{array}$ & $\begin{array}{c}29 \\
179 \\
16 \\
159 \\
49 \\
\end{array}$ & $\begin{array}{l}X 2=6.193 \\
p=0.18\end{array}$ \\
\hline Total & $22(5.1)$ & $4410(94.9)$ & 432 & \\
\hline
\end{tabular}




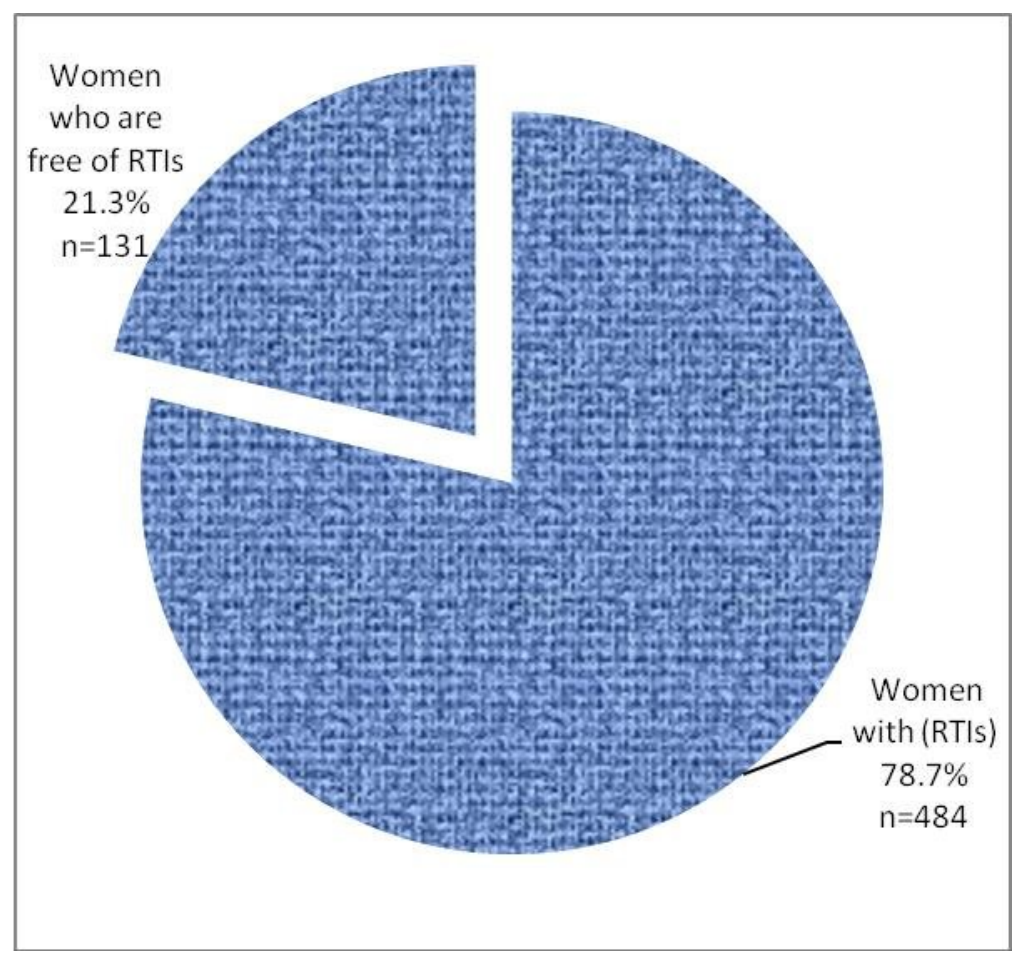

Figure (1) Prevalence of RTIs among studied women in the four family planning clinics

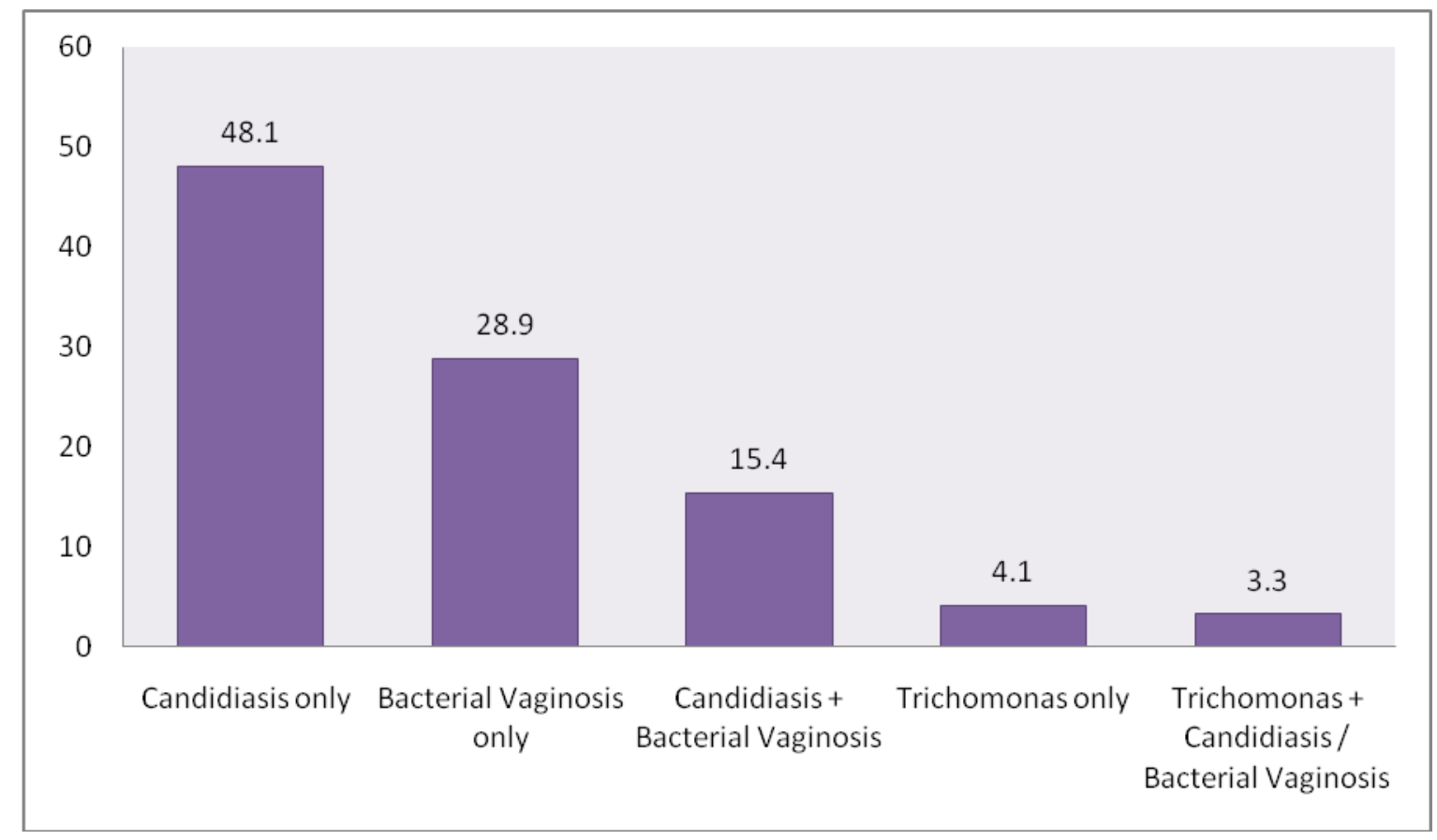

Figure (2) Types of RTIs among studied women 